\title{
THERMAL EVALUATION OF GREEN ROOFS AND SHINGLE ROOFS IN RESIDENTIAL AREAS FOR SUSTAINABLE URBAN ENVIRONMENTS
}

\author{
Serdar Celik*, Susan Morgan, Bill Retzlaff \\ Southern Illinois University Edwardsville, Edwardsville, Illinois, 62026, USA
}

\begin{abstract}
In this study, thermal performance evaluation of a selected region in Alton, Illinois is performed for two scenarios; one with all roofs covered with plants (green roofs), and the other one with conventional shingle roofs. Data for both roof structures comes from a prior experimental study that was conducted at Southern Illinois University Edwardsville. The purpose of this study is to use the obtained data and pertinent theory to determine thermal performance of buildings in a given region with the purpose of focusing on urban sustainability in residential areas. Roof systems that are considered are at three slope angles: $1^{\circ}, 20^{\circ}$, and $40^{\circ}$. Thermal data from this experimental analysis is used to estimate the difference in total cooling load in buildings for the selected region. Image processing technique was used to determine the total roof area in the pilot region. To better understand the convective heat transfer over the rooftops due to wind flow, roof-wind interactions were also studied numerically using ANSYS software. Results showed that a residential green roof system can yield significant energy savings due to enhanced thermal insulation. This would lead to a noticeable reduction in carbon footprints for urban areas, contributing to a more sustainable environment.
\end{abstract}

KEY WORDS: Green roofs, thermal performance, image processing, energy savings

\section{INTRODUCTION}

Approximately $48 \%$ of the overall residential energy consumption in the U.S. is attributed to heating and cooling [1]. This is a significant share of the total energy consumption to underline the importance of building insulation. There are numerous examples of building insulation techniques and materials. Most of the materials studied are synthetic insulation materials. Green roofs, on the other hand, offer an alternative, live insulation system with competitive R-values. Besides their thermal benefits, green roofs also play a significant role in reducing the urban heat-island effect, controlling storm water runoff, capturing atmospheric carbon dioxide, and increasing the life-span of roofing materials. Green roofs have been gaining popularity worldwide due to regulations and incentives in North America [2], Europe [3, 4], and Asia [5].

By reducing the heat flux through a rooftop and, thereby, reducing the average indoor temperature of a building, green roofs lead to a reduction in the energy demand of a building, especially during the warm season, which has been demonstrated by several energy consumption studies [6-8].

Thermal benefits and energy savings of green roofs have been investigated widely. Studies also exist on theoretical work conducted on these live insulation systems. Silva et al. [9] observed a Mediterranean example where Lisbon was selected as the location. Extensive, intensive, and semi-intensive green roof types were compared in this eco-region. Results demonstrated that energy savings between 20 and $70 \%$ with reference to black roofs can be achieved with green roof growth media depths varying from $0.1 \mathrm{~m}$ to $0.7 \mathrm{~m}$. 
Ascione et al. [10] compared the thermal benefits of green roofs and cool roofs for several cities in Europe. Berardi [11] looked at the microclimate benefits of green roofs that relate to the urban heat island effect. A remarkable reduction in the surrounding ambient temperature was observed around and atop buildings where green roofs were placed.

Celik et al. $[12,13]$ studied the effects of various growth media and plant types on thermal benefits of green roof systems both experimentally and theoretically. Sailor [14] investigated the evaporative cooling and evapotranspiration effects of green roof systems. Comerford et al. [15] conducted a study on the impact of energy performance certificate requirements on residential energy efficiency in the United Kingdom. The objective of the study was to assess the significance of the use of energy efficiency labels. The study showed that this kind of an approach carries a high potential to improve residential energy savings.

The objective of this paper is to show the energy savings potential for a residential area in Alton, Illinois. The quantitative analysis is based on the experimental work that was conducted on the design samples tested on Southern Illinois University Edwardsville campus. The following sections include the prior experimental work conducted, details about the selected geographic region, theoretical analysis, results and conclusion.

\section{PRIOR EXPERIMENTAL WORK}

Eighteen residential model roofs were designed, constructed and tested [16]. Frames were constructed to lift the rooftops and position them at one of the three slope angles studied: $1^{\circ}, 20^{\circ}$, and $40^{\circ}$. Nine of the roofs had shingles, while other nine had modular green roof systems on them. The experimental setup can be seen in Fig. 1.
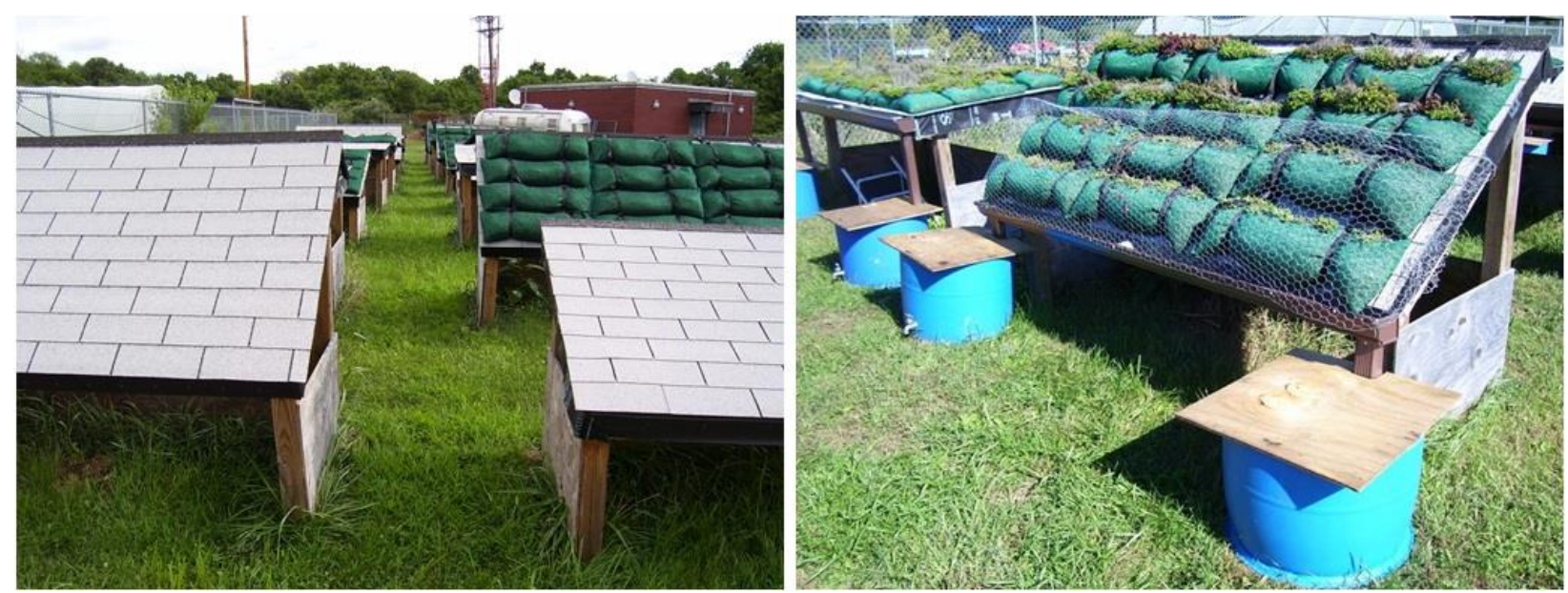

Fig. 1 Residential roof models.

For the modular green roof systems, a mix of seven Sedum species (S. kamtschaticum, S. reflexum, S. sexangulare, S. album, S. spurium, S. floriferum 'Weihenstaphaner Gold', and S. immergrunchen) were used. These plants can be seen in Fig. 2. 


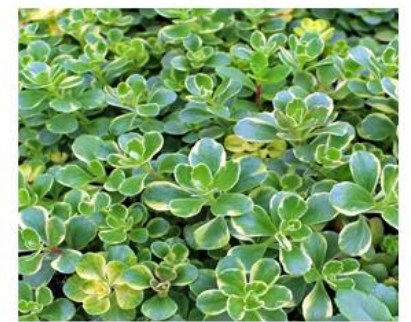

(a)

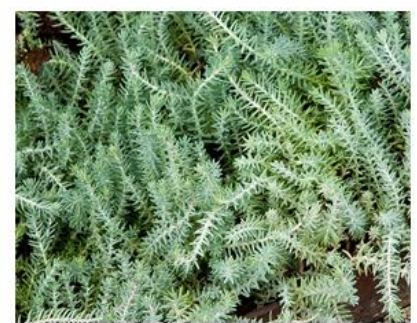

(b)

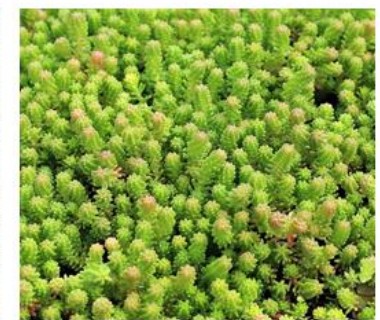

(c)

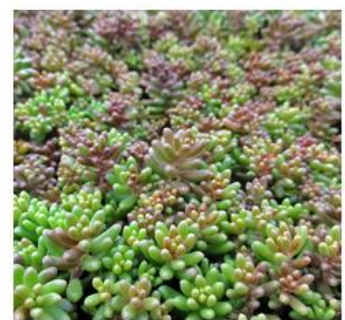

(d)

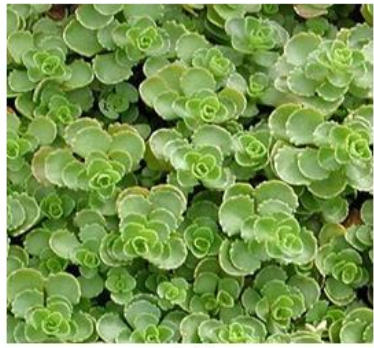

(e)

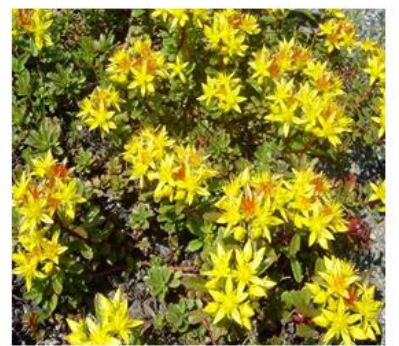

(f)

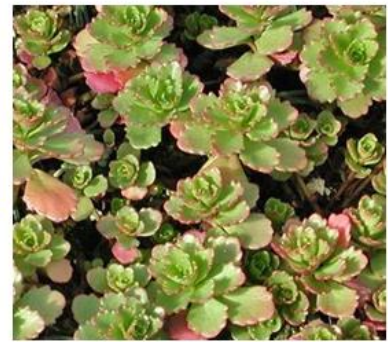

(g)

Fig. 2 Plants used: (a) S. kamtschaticum, (b) S. reflexum, (c) S. sexangulare, (d) S. album, (e) S. spurium, (f) S. floriferum 'Weihenstaphaner Gold', and (g) S. immergrunchen

\section{PILOT REGION}

Using Google Maps, the total area of the selected region was calculated. Total roof area within the pilot region was computed employing CVIPtools software. This image processing technique operates by first preprocessing and enhancing the image. It then determines the percent area of the target surface in terms of color coding of the pixels that make up the pre-processed image.

A section of Alton was selected as the pilot region. Fig. 3 illustrates the map view of the pilot region. A satellite view of the area with the boundaries of the pilot region can be seen in Fig. 4. The total area and the area of a highly vegetated portion of the enclosed region were calculated using Google Maps and are illustrated on the figure. Fig. 5 shows the pre-processed image of the region that was used to determine the approximate roof area. 

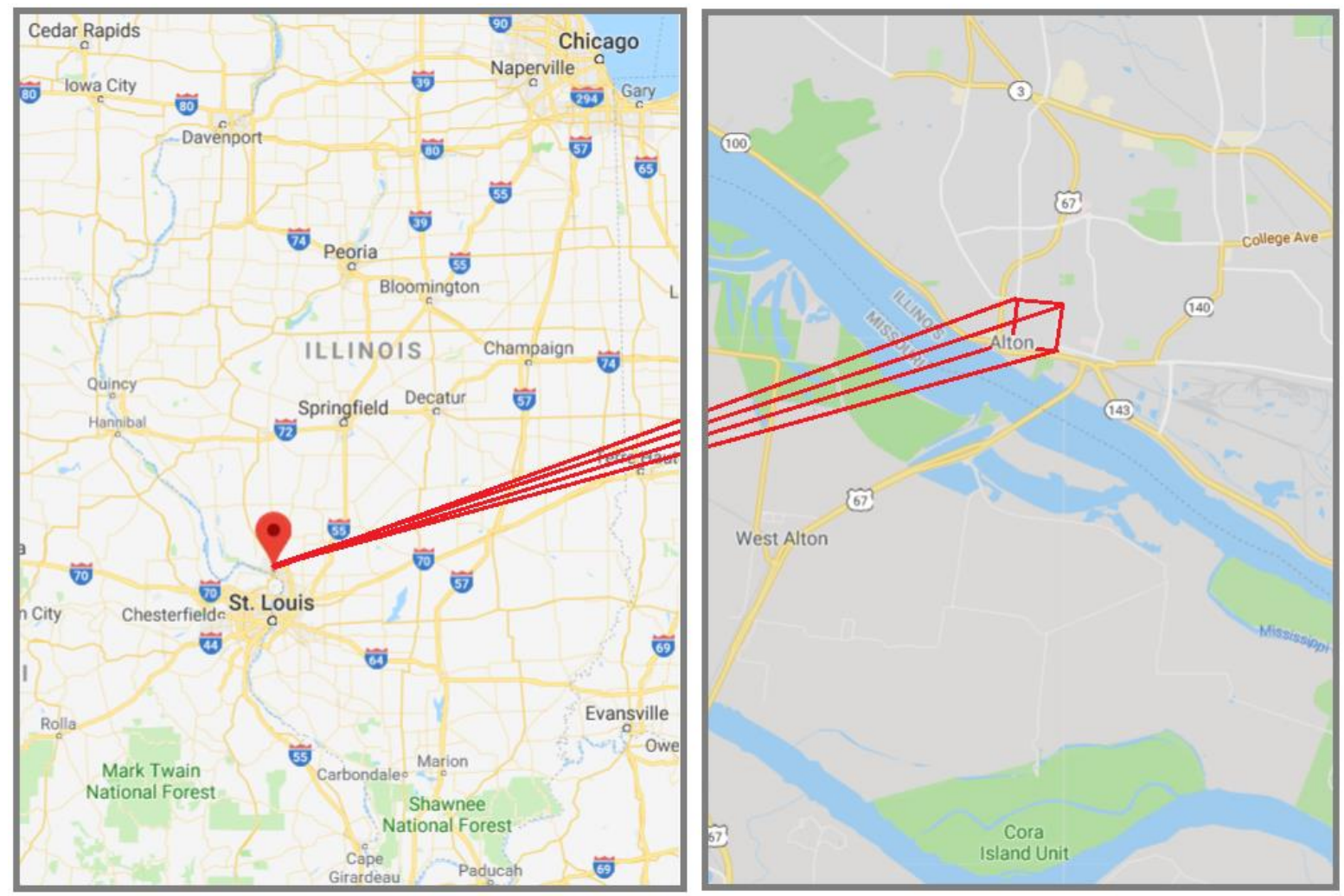

Fig. 3 Selected region.

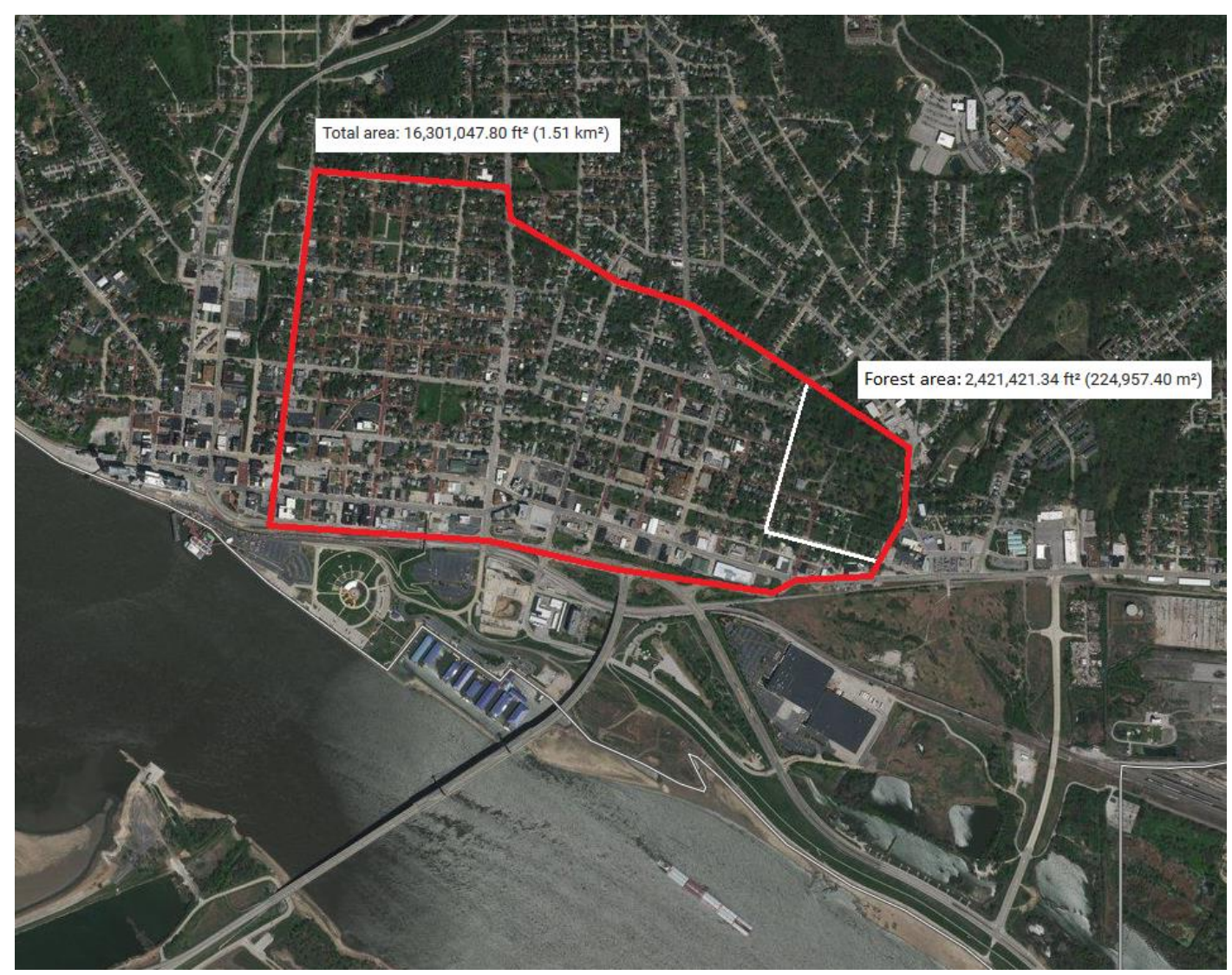

Fig. 4 Pilot region in Alton, Illinois. 


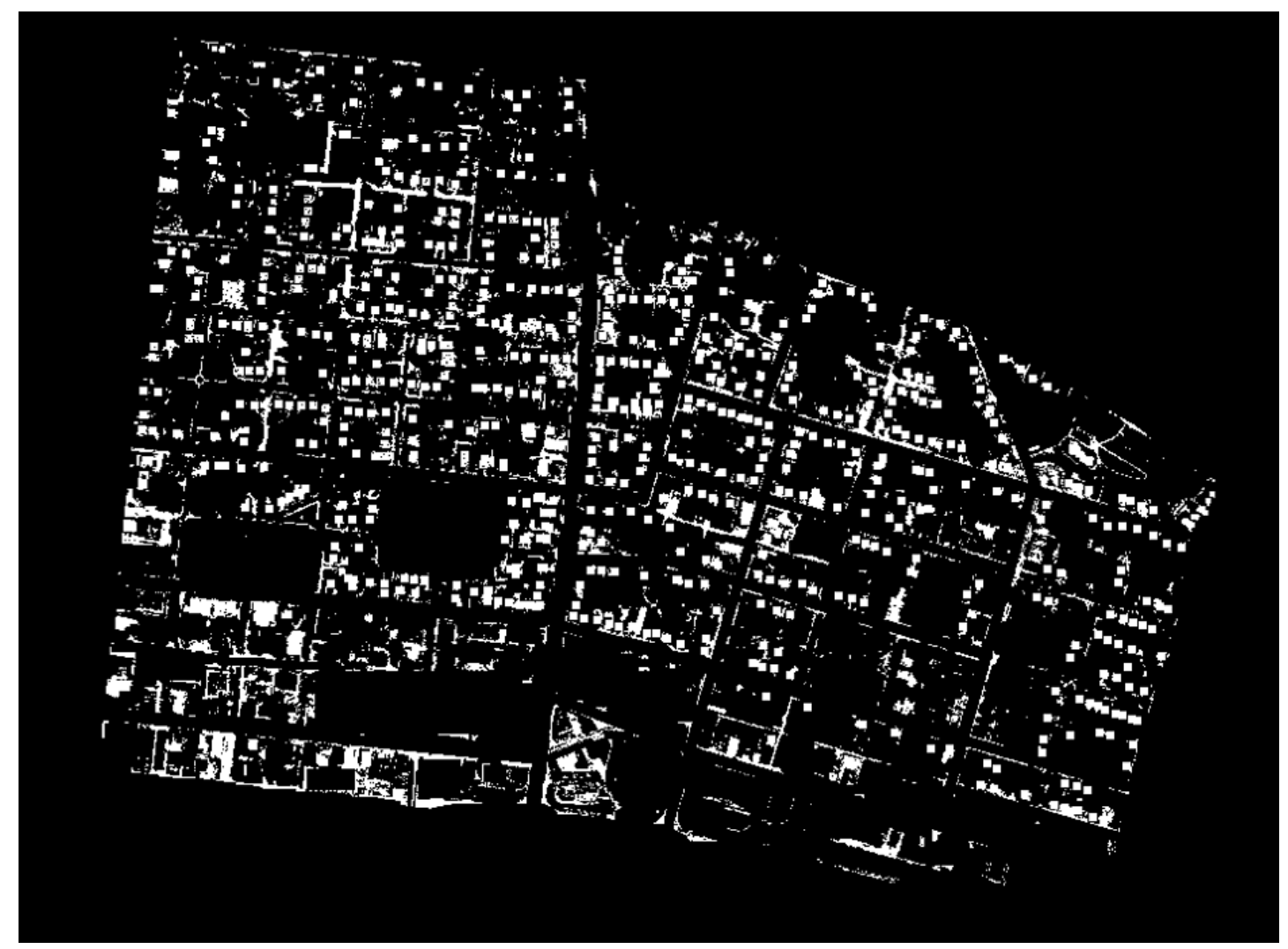

Fig. 5 Selected region after pre-processing where white color denotes the roofs of the buildings.

The histogram of the software showed that approximately $18 \%$ of the residential area was covered with roofs. The area values are listed in Table 1.

Table 1 Roof data of the pilot region selected.

\begin{tabular}{l|l}
\hline Total land area $\left(\mathrm{m}^{2}\right)$ & $1,510,000$ \\
Forest area $\left(\mathrm{m}^{2}\right)$ & 224,957 \\
Residential area $\left(\mathrm{m}^{2}\right)$ & $1,285,043$ \\
Approximate total roof area $\left(\mathrm{m}^{2}\right)$ & 231,308 \\
Roof-to-residential area ratio & 0.18 \\
\hline
\end{tabular}

Climate data for the region being studied is also required to evaluate the thermal performance of buildings that have green roofs. Annual temperature data for Alton is given in Fig. 6. This data is used in calculating the seasonal cooling loads for the selected residential area. 


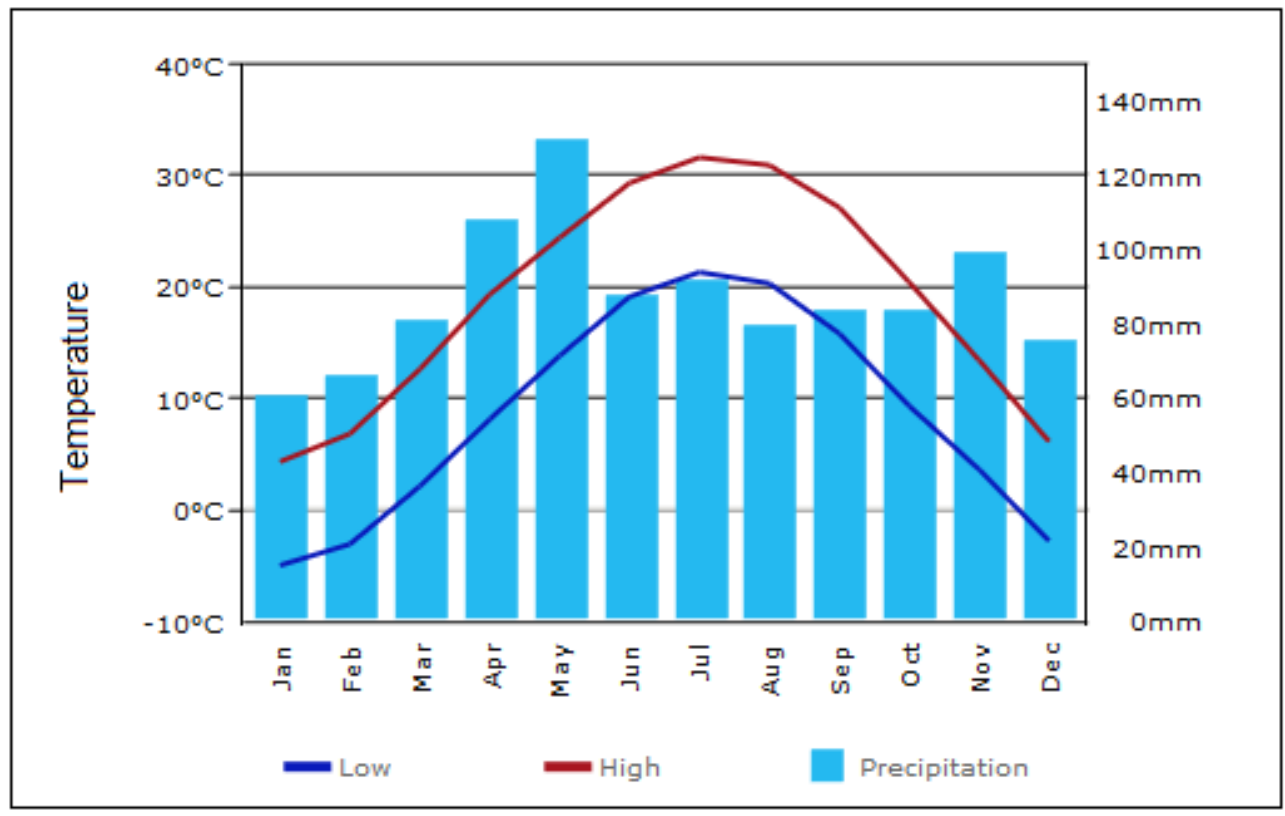

Fig. 6 Annual temperature data for Alton, Illinois (usclimatedata.com)

\section{THEORETICAL ANALYSIS}

Governing equations for the flow of air over the roof systems are listed below.

\section{Continuity:}

$\frac{\partial u}{\partial x}+\frac{\partial v}{\partial y}=0$

$x$-momentum:

$u \frac{\partial u}{\partial x}+v \frac{\partial u}{\partial y}=v \frac{\partial^{2} u}{\partial y^{2}}+\beta g\left(T_{r, b}-T_{a i r}\right) \cos \alpha$

Energy:

$$
\rho c_{p}\left(u \frac{\partial T}{\partial x}+v \frac{\partial T}{\partial y}\right)=k \frac{\partial^{2} T}{\partial y^{2}}
$$

\section{Roof - Wind Interaction:}

Convective heat transfer through the roof surface due to wind can be calculated by:

$Q_{\text {conv }}=h A\left(T_{s}-T_{\infty}\right)$ 
where $\mathrm{h}$ is the convective heat transfer coefficient, $\mathrm{A}$ is the roof surface area, and $\mathrm{T}_{\mathrm{s}}$ and $\mathrm{T}_{\infty}$ are roof and ambient air temperatures, respectively. Convective heat transfer coefficient at varying wind speeds on a plane surface can be determined by using the correlations suggested by Jürges [18].

$$
\begin{array}{ll}
h=4.0 U_{\infty}+5.6 & U_{\infty}<5.0 \mathrm{~m} / \mathrm{s} \\
h=7.1 U_{\infty}^{0.78} & U_{\infty}>5.0 \mathrm{~m} / \mathrm{s}
\end{array}
$$

As for the green roof structures, the impact of plants should also be included in the analysis. Sensible heat flux over a green roof can be calculated as suggested by Frankenstein and Koenig [19]:

$$
H=\rho_{a g} C_{p, a} C_{h g} W_{a f}\left(T_{a f}-T_{g}\right)
$$

where $\rho_{\mathrm{ag}}$ is the density of air near the soil surface, $\mathrm{C}_{\mathrm{p}, \mathrm{a}}$ is the specific heat of air at constant pressure, $\mathrm{C}_{\mathrm{hg}}$ is the bulk transfer coefficient, $\mathrm{W}_{\mathrm{af}}$ is the wind speed above the growth medium, $\mathrm{T}_{\mathrm{af}}$ is the air temperature within the plant canopy, and $\mathrm{T}_{\mathrm{g}}$ is the temperature of the growth medium. Wind speeds above the green roof systems were approximated to be the equal to the air velocity over the shingle roof with no vegetation. Average velocities were obtained by CFD using ANSYS software.

Energy consumption of the existing buildings was calculated based on the thermal resistance values with the green roofs on top of the existing white roofs. These values were experimentally obtained in a prior study [12].

\section{RESULTS}

Energy savings and carbon footprint reduction results for the pilot region are provided in Table 2. Energy savings results are obtained for a cooling season based on an experimental work conducted at a green roof research field site at Southern Illinois University Edwardsville (SIUE) [16]. Roof cooling load during the daytime was obtained based on the temperature measurements from the top of the green roof blocks and from the ceiling of the scaled model buildings. A Red Dragon GT-1000 non-contact infrared thermometer (temperature range $-50^{\circ}$ to $400^{\circ} \mathrm{C}$, accuracy $+/-2 \%$, distance to spot size ratio 9:1) was used to measure the temperatures of the undersides of the roof decks. Measurements were made by aiming the thermometer at the marks from a distance of $60 \mathrm{~cm}$. Temperatures were recorded once every other week at sunrise, midday, and sunset for three summer months. 


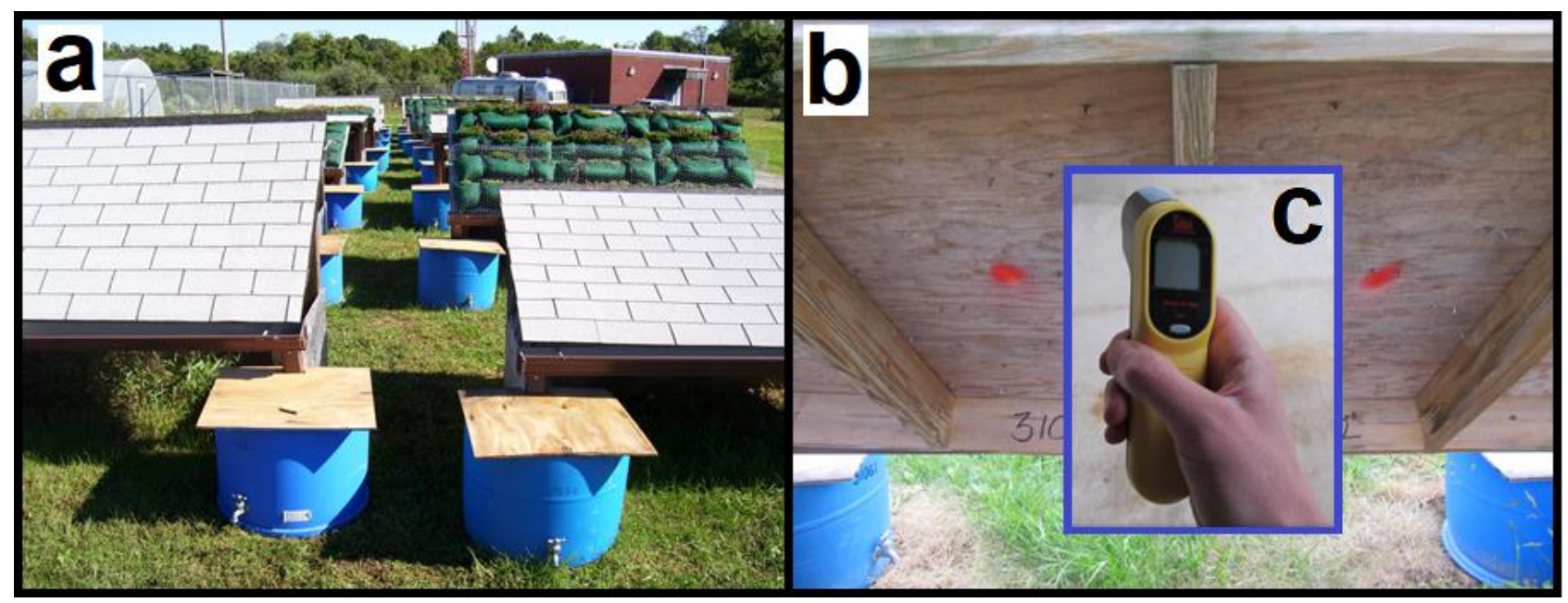

Fig. 7 (a) Scaled model green and shingle roofs at SIUE research field site, (b) ceiling at the back with marks for measuring temperatures, (c) the infrared thermometer [17]

Summer season cooling energy consumption per unit area was calculated for June $1^{\text {st }}$ - August $31^{\text {st }}$ time period for a selected indoor design temperature of $20^{\circ} \mathrm{C}$ and an outdoor average temperature as given in Fig. 6. The values were obtained for the models with shingle roof and were assumed as a baseline to compare with the models having green roof atop. Energy savings with green roofs were calculated based on the increase in the R-value of the roof system with the added vegetation and growth media.

Carbon footprint analysis was conducted for two different sources of reduction, (i) due to energy savings and (ii) due to carbon sequestration with the added vegetation. Carbon footprint reduction due to energy savings was calculated based on the $\mathrm{kg} \mathrm{CO}_{2} \mathrm{e}$ per $\mathrm{kWh}$ values given by U.S. Energy Information Administration for Illinois State [20]. Carbon sequestration values were calculated based on a study performed by Getter et al. [21]. Their study was selected as the sedum types observed in their study matched the sedums that were used in this analysis. 
Table 2 Total anticipated energy savings for the selected region in Alton, Illinois

\begin{tabular}{|c|c|c|c|c|c|c|}
\hline \multirow[b]{2}{*}{ Slope angle } & \multicolumn{3}{|c|}{ Green Roof } & \multicolumn{3}{|c|}{ Shingle Roof } \\
\hline & $1^{\circ}$ & $20^{\circ}$ & $40^{\circ}$ & $1^{\circ}$ & $20^{\circ}$ & $40^{\circ}$ \\
\hline Roof area $\left(\mathrm{m}^{2}\right)$ & 231,308 & 246,112 & 301,857 & 231,308 & 246,112 & 301,857 \\
\hline $\begin{array}{l}\text { Roof cooling load during } \\
\text { daytime, sunrise to sunset } \\
\text { (kW/daytime) }\end{array}$ & 64.71 & 68.85 & 83.19 & 130.21 & 140.54 & 167.98 \\
\hline $\begin{array}{l}\text { Roof cooling load per unit roof } \\
\text { area }\left(\mathrm{W} / \mathrm{m}^{2} / \text { day }\right)\end{array}$ & 0.280 & 0.280 & 0.276 & 0.563 & 0.571 & 0.556 \\
\hline $\begin{array}{l}\text { Summer seasonal }{ }^{*} \text { cooling } \\
\text { energy consumption per unit } \\
\text { area }\left(\mathrm{kWh} / \mathrm{m}^{2}\right)\end{array}$ & 0.365 & 0.365 & 0.360 & 0.735 & 0.745 & 0.726 \\
\hline $\begin{array}{l}\text { Seasonal cooling energy } \\
\text { consumption }(\mathrm{kWh})\end{array}$ & 84,400 & 89,800 & 108,600 & 169,900 & 183,400 & 219,200 \\
\hline $\begin{array}{l}\text { Seasonal cooling energy savings } \\
\text { of green roofs with reference to } \\
\text { shingle roofs }(\mathrm{kWh})\end{array}$ & 85,500 & 93,600 & 110,600 & Baseline & Baseline & Baseline \\
\hline $\begin{array}{l}\text { Seasonal cooling energy savings } \\
\text { of green roofs with reference to } \\
\text { shingle roofs }(\$)^{* * *}\end{array}$ & 4,667 & 5,108 & 6,041 & Baseline & Baseline & Baseline \\
\hline $\begin{array}{l}\text { Seasonal carbon footprint } \\
\text { reduction of green roofs with } \\
\text { reference to shingle roofs due to } \\
\text { energy savings }\left(\mathrm{kg} \mathrm{CO}_{2} \mathrm{e}^{* * * *}\right.\end{array}$ & 32,826 & 35,928 & 42,489 & Baseline & Baseline & Baseline \\
\hline $\begin{array}{l}\text { Seasonal carbon sequestration } \\
\text { due to added vegetation on the } \\
\text { roofs }\left(\mathrm{kg} \mathrm{CO}_{2} \mathrm{e}\right)^{* * * * *}\end{array}$ & 43,717 & 46,515 & 57,051 & 0 & 0 & 0 \\
\hline $\begin{array}{l}\text { Seasonal total carbon reduction } \\
\text { with green roofs }\left(\mathrm{kg} \mathrm{CO}_{2} \mathrm{e}\right)\end{array}$ & 76,543 & 82,443 & 99,540 & Baseline & Baseline & Baseline \\
\hline
\end{tabular}

${ }^{*}$ Covers a 90-day summer period for which experimental data was collected (June-August) [16]

** Values were calculated based on the unit electricity price of $0.0546 \$ / \mathrm{kWh}[20]$

${ }^{* * *}$ Values were calculated based on the carbon footprint value of $0.384 \mathrm{kgCO}_{2} \mathrm{e} / \mathrm{kWh}$ for Illinois [21]

${ }^{* * * * *}$ Carbon sequestration values were obtained from a study of Getter et al. [22]

Wind-roof interaction for the buildings was also studied. Ansys was utilized in obtaining velocity distribution of air and streamlines around the roof at all three roof slopes $\left(1^{\circ}, 20^{\circ}\right.$, and $\left.40^{\circ}\right)$. The results are illustrated in Figures 8-13. 


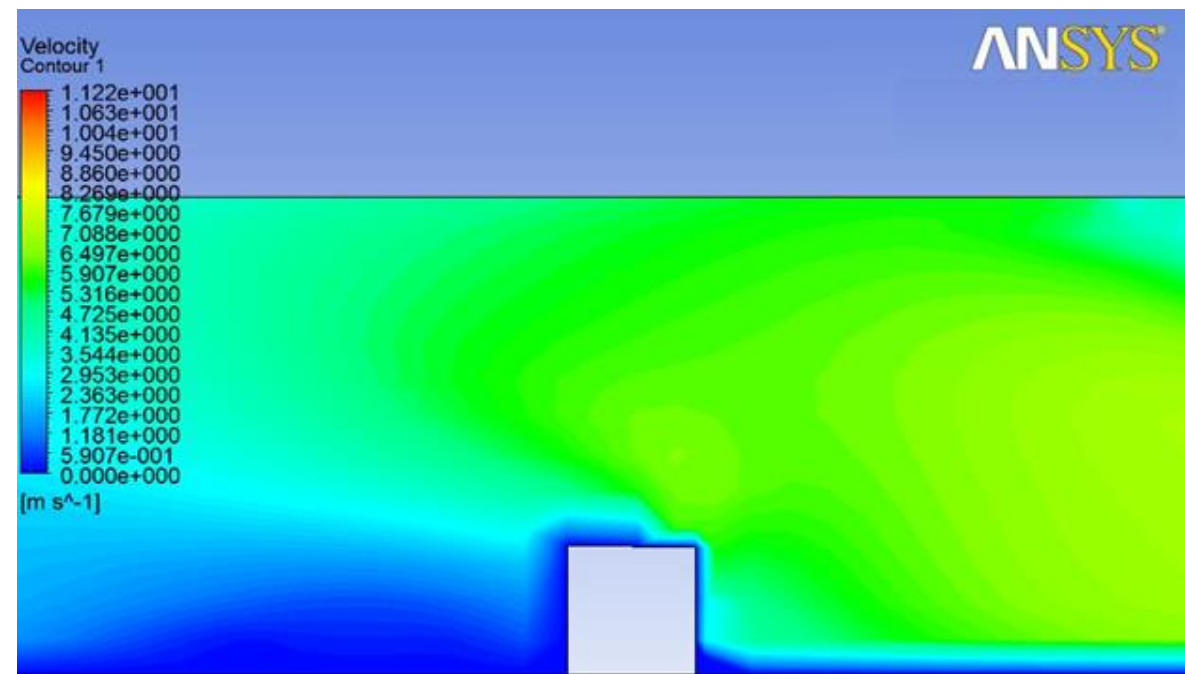

Fig. 8 Velocity profile for $1^{\circ}$ roof slope (wind speed: $25 \mathrm{kph}$ )

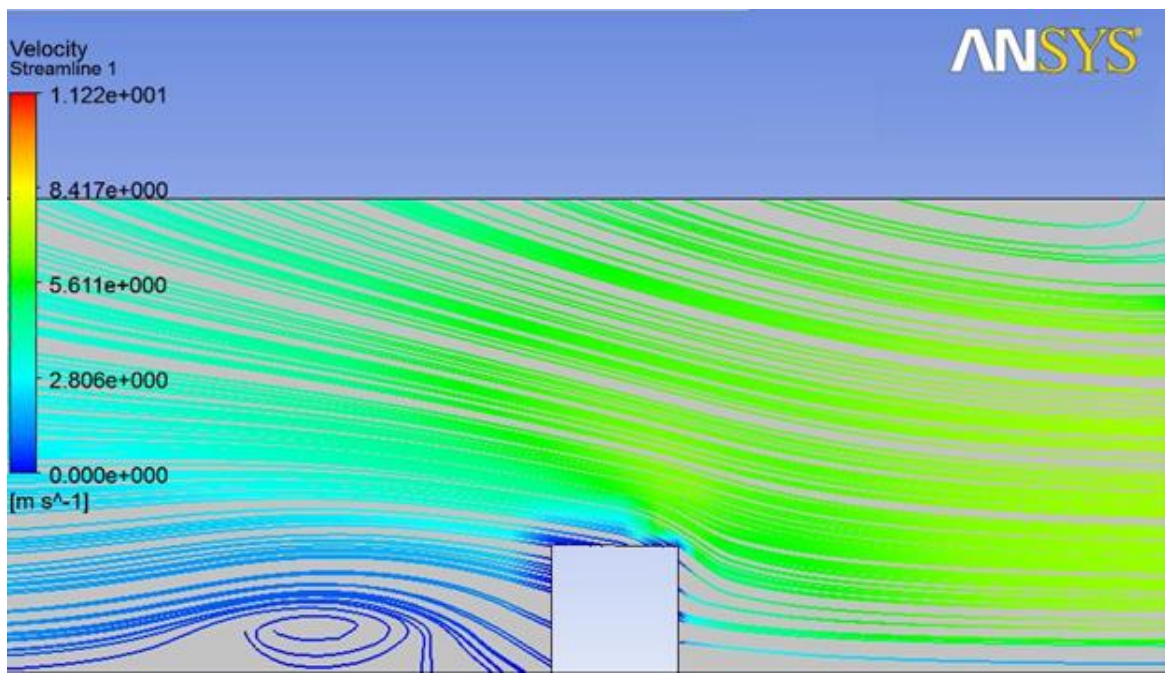

Fig. 9 Streamlines for $1^{\circ}$ roof slope (wind speed: $25 \mathrm{kph}$ )

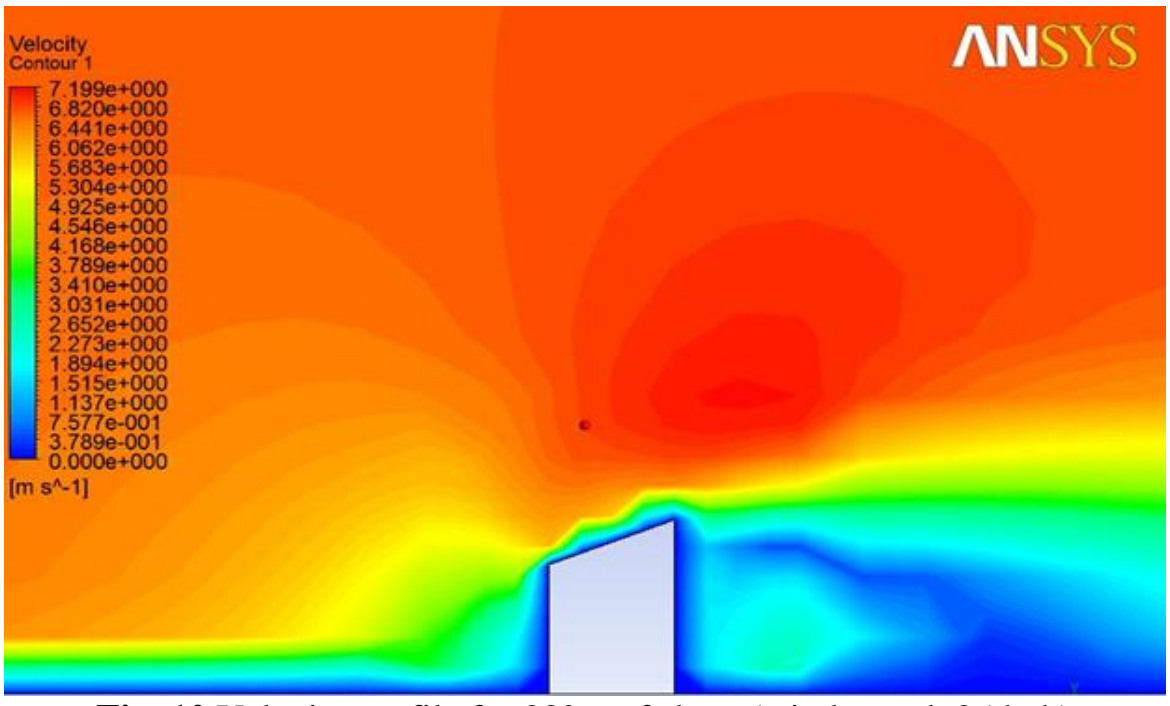

Fig. 10 Velocity profile for $20^{\circ}$ roof slope (wind speed: $25 \mathrm{kph}$ ) 


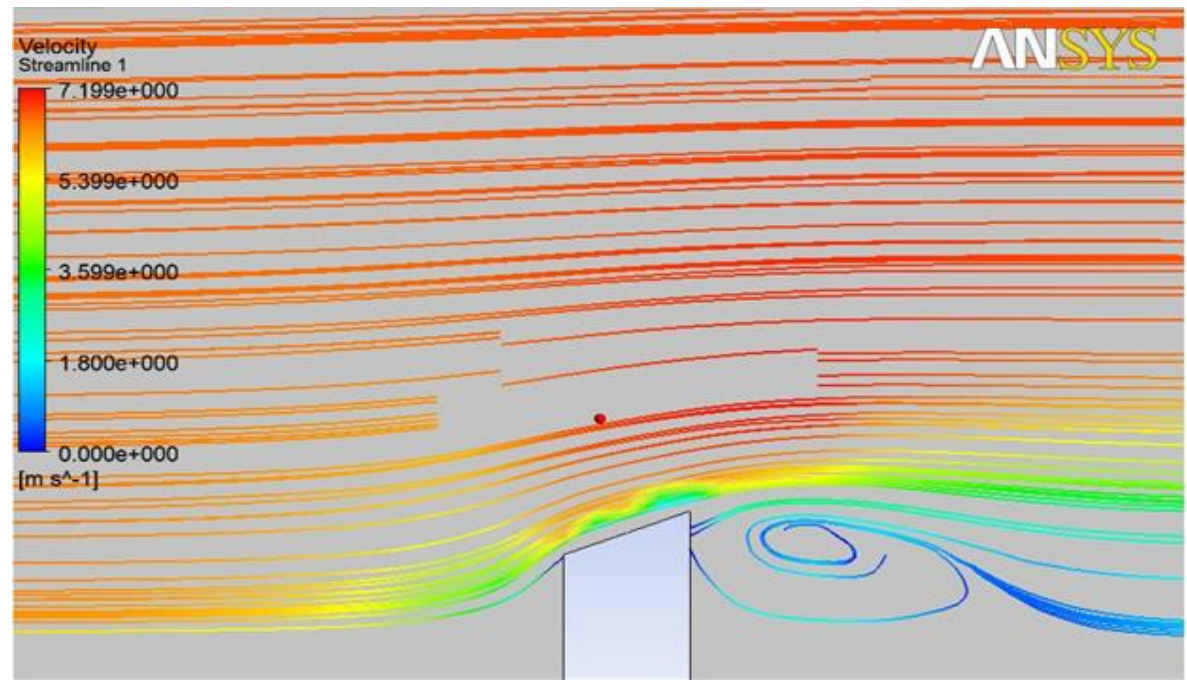

Fig. 11 Streamlines for $20^{\circ}$ roof slope (wind speed: $25 \mathrm{kph}$ )

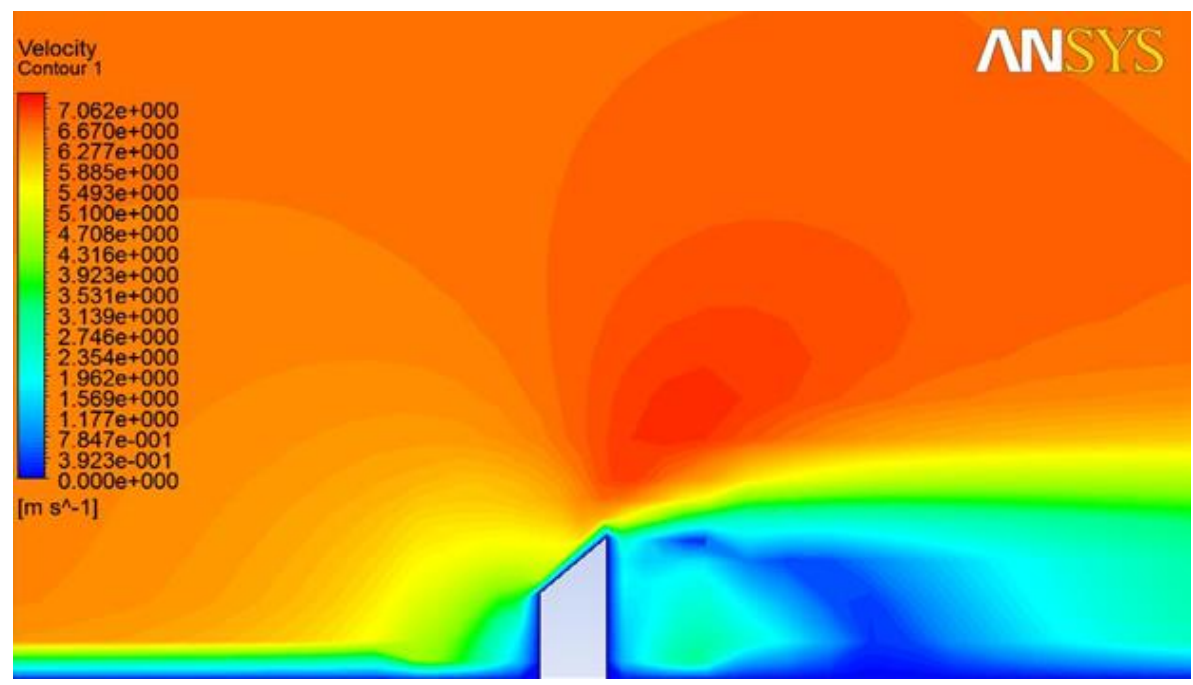

Fig. 12 Velocity profile for $40^{\circ}$ roof slope (wind speed: $25 \mathrm{kph}$ )

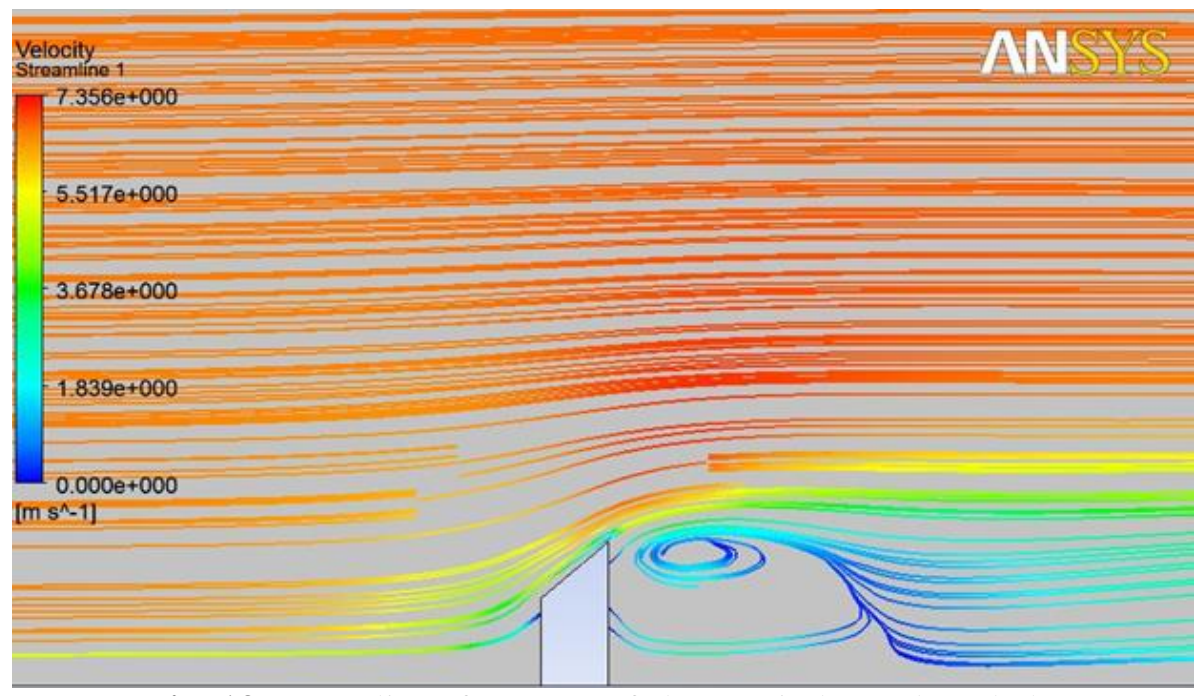

Fig. 13 Streamlines for $40^{\circ}$ roof slope (wind speed: $25 \mathrm{kph}$ ) 
The results from the CFD analysis yield the average air velocities at a given height from the roof. This analysis helps in determining convective cooling on roof surfaces and potential wind uplift risks for green roof applications over the roofs.

\section{CONCLUSIONS}

Energy savings and carbon footprint reduction potential for a pilot region in Alton, Illinois in the United States of America was studied for a case of converting shingle roofs into green roofs for the residential units. All studies were done for three roof slopes $\left(1^{\circ}, 20^{\circ}\right.$, and $\left.40^{\circ}\right)$. An energy savings analysis was performed based on prior experimental studies on the thermal performance of select growth media and plants. The wind-roof interaction was also studied to determine convective cooling on roof surfaces and potential wind uplift risks for green roof applications over the roofs. It was observed that the convective heat transfer rate increased with increasing roof slope due to elevated air velocity over the roof surface. Approximate total roof area in the selected region was determined using a satellite image and an image processing technique. Carbon footprint analysis was conducted accounting for two sources of reduction, (i) due to energy savings and (ii) due to the carbon sequestration with the added plant coverage on all the residential roofs in the area. The results showed that implementation of green roofs to all residential roofs in the selected pilot region could result in an energy savings in the range of 85.5-110.6 MWh with respect to the case of shingle roofs, which is equivalent to an additional $8-10$ residences based on an average annual electricity consumption of $10,766 \mathrm{kWh}$ [23]. Total carbon footprint reduction with reference to the shingle roofs was calculated to be in the range of 76.5-99.5 $\mathrm{t} \mathrm{CO}_{2} \mathrm{e}$. These numbers indicate the significance of green roof applications in terms of their energy savings and carbon emission reduction. It should be noted that the indirect energy savings due to the reduction in urban heat island effect have not been accounted for in this study. With the added benefit of reduced urban heat island for the pilot region, energy savings would increase.

\section{NOMENCLATURE}

$\begin{array}{llllll}A & \text { area } & \left(\mathrm{m}^{2}\right) & T & \text { temperature } & (\mathrm{K}) \\ c & \text { specific heat } & \left(\mathrm{J} \mathrm{kg}^{-1} \mathrm{~K}^{-1}\right) & W & \text { wind speed } & \left(\mathrm{m} \mathrm{s}^{-1}\right) \\ h & \text { convective heat transfer coeff. } & \left(\mathrm{W} \mathrm{m} \mathrm{K}^{-2} \mathrm{~K}^{-1}\right) & \beta & \text { thermal expansion coeff. } & \left(\mathrm{K}^{-1}\right) \\ k & \text { thermal conductivity } & \left(\mathrm{W} \mathrm{m}^{-1} \mathrm{~K}^{-1}\right) & \rho & \text { density } & \left(\mathrm{kg} \mathrm{m}^{-3}\right)\end{array}$

\section{REFERENCES}

[1] U.S. Department of Energy website, https://energy.gov/public-services/homes/heating-cooling, Accessed September 6, 2019. Webpages: Nonperiodical Web Document

[2] Taylor, D.A. Growing green roofs, city by city. 2007. Environmental Health Perspectives, 115(6):A307-A311. Journal Paper

[3] Li, W.C., Yeung, K. A., 2014. A comprehensive study of green roof performance from environmental perspective. International Journal of Sustainable Built Environment 3 (1), 127-134. Journal Paper

[4] Berndtsson, J. C., Bengtsson, L., Jinno, K., 2009. Runoff water quality from intensive and extensive vegetated roofs. Ecological Engineering 35, 369-380. Journal Paper

[5] James, N., G. Metternicht, 2013. How to grow a green roof industry. Cities Alive: $11^{\text {th }}$ Annual Green Roof and Wall Conference Proceedings, 1 - 14. Conference Proceedings

[6] Sonne, J. 2006. Evaluating green roof energy performance. ASHRAE Journal 48:59-61. Journal Paper

[7] Saiz, S., C. Kennedy, B. Bass, and K. Pressnail. 2006. Comparative life cycle assessment of standard and green roofs. Environmental Science and Technology 40:4312-4316. Journal Paper

[8] Sfakianaki, A., E. Pagalou, K. Pavlou, M. Santamouris, and M. N. Assimakopoulos. 2009. Theoretical and experimental analysis of the thermal behavior of a green roof system installed in two residential buildings in Athens, Greece. International Journal of Energy Research. 33:1059-1069. Journal Paper 
[9] Silva, C., Gomes, M. G., Silva, M., 2016. Green roofs energy performance in mediterranean climate. Enegy and Buildings 116, 318-325. Journal Paper

[10] Ascione, F., Bianco, N., De Rossi, F., Turni, G., Vanoli, G. P., 2013. Green roofs in European climates. Are effective solutions for the energy savings in air-conditioning? Applied Energy 104, 845-859. Journal Paper

[11] Berardi, U., 2016. The outdoor microclimate benefits and energy saving resulting from green roofs retrofits. Energy and Buildings 121, 217-229. Journal Paper

[12] Celik, S., S. Morgan, W.A. Retzlaff, Energy conversation analysis of various green roof systems, IEEE Green Technologies Conference, Grapevine, TX, April 15-16, 2010. Conference Proceedings

[13] Celik, S., S. Morgan, W.A. Retzlaff, O. Once, Thermal insulation performance of green roof systems, $6^{\text {th }}$ International Green Energy Conference, Eskisehir, Turkey, 5-9 June, 2011. Conference Proceedings

[14] Sailor, D. J., 2008. A green roof model for building energy simulation programs. Energy and Buildings 40, 1466-1478. Journal Paper

[15] Comerford, D. A., Lange, I., Moro, M., 2018. Proof of concept that requiring energy labels for dwellings can induce retrofitting. Energy Economics 69, 204-212. Journal Paper

[16] Celik, S., D. Murphy, S. Morgan, W. Retzlaff, 2019. Thermal performance evaluation of sloped green roofs and shingle roofs. Journal of Living Architecture, 6 (1), pp. 15-30. Journal Paper

[17] Murphy, D. Evaluation of the thermal performance and storm water runoff retention of a residential green roof system. Master's Thesis, Southern Illinois University Edwardsville, 2012. Thesis

[18] Jürges, W. 1924. The heat transfer at a flat wall (Der Wärmeübergang an einer ebenen Wand), Beihefte zum Gesundh.-Ing., 1, pp. 19-23. Book

[19] Frankenstein, S. and Koenig, G.G. 2004. Fast all- season soil strength. TR-04-25. Hanover, NH: US Army Engineer Research and Development Center, Cold Region Research and Development. Technical Report

[20] Ameren Illinois website, https://www.chooseenergy.com/shop/residential/electricity/IL/62002/ameren-il-electricity/, Accessed October 9, 2019. Webpages: Nonperiodical Web Document

[21] U.S. Energy Information Administration website, https://www.eia.gov/electricity/state/, Accessed October 9, 2019. Webpages: Nonperiodical Web Document

[22] Getter, K.L., Rowe, B.D., Robertson, G.P., Cregg, B.M., Andresen, J.A. Carbon sequestration potential of extensive green roofs. Environmental Science and Technology 43 (19), 7564-7570. Journal Paper

[23] U.S. Energy Information Administration, Residential Energy Consumption Survey, www.eia.gov/consumption/residential, Accessed October 20, 2019. Webpages: Nonperiodical Web Document 